\title{
INTRODUCTION
}

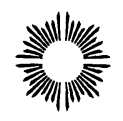

Tucio victorio mansilla's Una excursión a los indios ran1 queles first appeared in La Tribuna of Buenos Aires in irregular, although almost daily, installments between 20 May and 7 September 1870. Mansilla had taken copious notes while on his singular, eighteen-day expedition some six weeks earlier, and what he did not fully compose in the field or at his post as commander of the new army fort at Rio Cuarto, he feverishly dictated as the typesetters at La Tribuna stood waiting. The sixty-six chapters Mansilla finished in this fashion, plus two more and an epilogue he added as La Tribuna prepared to publish the work in its entirety at year's end, comprised, essentially, the Excursion as it is still known, and still read, in Argentina today.

Whatever genre scholarly consideration may finally determine best suits Mansilla's creation, the book can be said to claim certain unquestionable achievements. It is one of very few works of either North or South American letters which present a vivid and sustained firsthand account of noncombative coexistence between American Indian and white civilization, on Indian land, during any nation's period of consolidation. Noted in its own country for its wit, adventure, and narrative ingenuity, it brings original insight to Western questions of "civilization and barbarism," immigration, ethnic and racial diversity, and land ownership and tenancy. Mansilla's narrative tests the postulates of Argentine thinkers such as Juan Bautista Alberdi and Domingo Faustino Sarmiento. The barbarism of frontier society, the superiority of European races, the irreconcilability of the emerging nation with its indigenous populations - these were the bedrock suppositions which Mansilla bore to the Ranquel settlements beyond the pampas. He himself did not embrace these ideas. He chose instead, and largely alone, to espouse dialogue and a candid, even Rabelaisian diplomacy-there 
was a kind of haphazard agape to his approach - as the best way to engage the "Indian problem." The Excursión thus presents an eighteen-day dress rehearsal, complete with an arduous summit conference under the desert sun, Socratic point-counterpoint colloquia with the chiefs, elders, and braves, and hospitality on Ranquel protocol. It was all intended in Mansilla's mind as groundwork for a reconciliation between antagonists that never finally took place.

The Excursion is a gold mine of diversity. An epistolary serial narrative dedicated to a maverick Chilean writer and globe-trotter named Santiago Arcos, it was penned by a worldly-wise, forty-oneyear-old Mansilla, scion of the Argentine commercial and governing elite and nephew of the deposed dictator Juan Manuel de Rosas. It is a military chronicle as well, one in which Colonel Mansilla carries out an authorized and peaceful foray of his own design into Indian territory. The book also advances a testimonial tradition practiced since the arrival of the Spanish in at least two inflections: the expeditionary and captivity narrative and the missionary "relation." The book is furthermore a travel chronicle, the fruit of an extraordinary expedition headed by a quixotic colonel of the Argentine army. It differs in three respects from the military writings on the "conquest of the desert" that would follow Mansilla's narrative some nine years and many thousands of Indian and army dead later: it is about communication rather than conquest, it presents a multitude of vividly drawn characters, and its author was a literary celebrity.

Mansilla's relationship to the inhabitants on both sides of the frontier line was perforce more intimate, certainly more complex, than that of any of the travel writers before or since his sojourn. He had, among other things, reputation, personal safety, and both a family and a military career to consider in undertaking and recording the expedition. Mansilla's book may therefore be said to occupy a place as a forerunner of the testimonial literature which, in part, characterized the works of the "Generation of 1880 ," of which Mansilla would become a member in good standing. Anecdotal, glib, long on self-indulgence and short on character development, this would be the literature of a leisurely, proprietary class of comfortable witnesses. Small wonder, then, that it should often have taken the form of letters, as it does in the Excursion, or that it should frequently deliver shared confidences and pleasantries.

The Excursion, however, is incalculably more powerful than the 
exiguous demands of its genre might suggest. In the first place, Mansilla's strategies for dramatizing his interaction with the frontier society are ingenious. He weaves endless sub-narratives and digressions through the basic expeditionary account: stories of Christian captives long accustomed to Indian ways; asides in which Ranquels cajole the colonel to meet with them after the parlamento to drink; unfinished homilies to which he gives wry titles such as "Morality Applied to Politics, or the Art of Waiting"; and tonguein-cheek translations, as in "the pleasure of a drink with you" for the Ranquels' exclamatory "Yapai!" Secondly, Argentina, like many nations on both American continents, stood in puzzled ambivalence vis-à-vis the indigenous peoples inhabiting land which nationalist expansionism demanded for the nation. Of what integrity may a nation hope to boast, Mansilla's latent question seems to be, if it does not know its own people, or if its people have no voice in its dialogue with the rest of the world? It was one thing to pose this question to one's peers over, say, absinthe in the safety of a paneled drawing room or to brandish it as political badinage at the jockey club. It was another to bring back living literary evidence of the answer it might draw in a tête-à-tête with the chief of the Ranquel nation.

In translation, the Excursion delivers something new to Englishspeaking readers. At the time Mansilla rode out with his eighteen soldiers, scouts, and friars to break bread and talk peace with Chief Mariano Rosas, Argentina was, like the United States, a young Western nation locked into a scheme of relentless westward expansion. It defined itself as sprung from white European colonists and immigrants, and it acknowledged as its intellectual masters men who pressed at every turn for the modernization of social and political processes along lines of racial and economic privilege. Alberdi wrote in 1852 that to govern was to populate, and Argentina's doors would soon be opened to staggering numbers of immigrants. Few voices other than Mansilla's were heard to say that Argentina already had people, had a people, who could assume stewardship of the land.

The leading ideologues of Argentine society had chosen instead to confront the coveted territory's Ranquel, Araucanian, and Pampa nations and tribes with ever more dire propositions of assimilation. The book explores, among other things, the disquieting moral and ideological questions lost on those who went forward with the making of a nation with no better preparation for the task 
than that which a rigid deference to property-based expansionism might be expected to provide. The Excursion may finally be only a recording of the possibilities inherent in the meeting of EuroAmerican and Native American cultures without the threat of immediate armed confrontation. Even in this modest but unattainable purpose, however, it has had few equals on either American continent.

\section{NOTE TO THE TRANSLATION}

This translation is based on the 1947 edition of Una excursion a los indios ranqueles published as part of the Biblioteca Americana by the Fondo de Cultura Económica (Mexico City and Buenos Aires). The FCE edition, under the care of Julio Caillet-Bois, itself followed the 1890 edition, the one most carefully overseen by the author. The translator has here and there judged some of Mansilla's rather private digressions as meriting a discreet pruning and has applied the shears as sparingly as possible. Certain obscure allusions to local personages, especially those intended by the author to answer other newspaper writings, have also been deleted at no discernible cost to narrative flow. The translator of course assumes full responsibility for these deletions, which in any case amount to no more than a small fraction of the overall text as published in Mansilla's lifetime. 